\title{
Evaluation of Factors Influencing the Sustainability and Outreach of Microfinance Institutions in Northern Ghana
}

\author{
Dr. Issahaku Salifu $^{1^{*}} \quad$ Dr. Muntari Mahama ${ }^{2 *} \quad$ Mr. Mohammed Dawuni ${ }^{3}$ \\ 1. Faculty of Business, Tamale Technical University, P. O. Box 3, E/R, Tamale, Northern Region, Ghana \\ 2. Faculty of Business, Tamale Technical University, P. O. Box 3, E/R, Tamale, Northern Region, Ghana \\ 3. Faculty of Applied Sciences, Tamale Technical University, P. O. Box 3, E/R, Tamale, Northern Region,
} Ghana

\begin{abstract}
Purpose: The study examined the factors that influenced the sustainability and outreach of microfinance institutions in northern Ghana from the view point of managers and operation staff of microfinance institutions.

Methodology: Questionnaires were administered to a sample of 181 managers and operation staff of 18 microfinance institutions in northern Ghana. Purposive and convenience sampling techniques were used. Data was analysed using Spearman multiple correlations.

Findings: The study found: a positive statistically significant relationship between capital structure and financial sustainability in northern Ghana, failed to uncover any statistically significant relationship between capital structure and outreach, failed to find statistically significant relationship between financial sustainability and outreach levels in northern Ghana, find a positive statistically significant relationship between capital structure, financial sustainability and outreach in northern Ghana.

Originality: The study adds to the literature on microfinance sustainability and outreach and in particular the Ghanaian context.

Limitation: The study is limited to only microfinance institutions operating in northern Ghana and the perceptions of finance professionals. The study suggests consideration of the entire regions of Ghana and the usage of actual loan data of microfinance institutions.
\end{abstract}

Keywords: Microfinance institutions, Ghana, poverty reduction, capital structure, sustainability, outreach.

DOI: $10.7176 /$ RJFA

DOI: $10.7176 /$ RJFA/10-16-16

Publication date: August $31^{\text {st }} 2019$

\section{Introduction}

In the last three decades, microcredit and microfinance have certainly received extensive recognition as a strategy for poverty reduction and for economic empowerment of the productive poor; in particular, in developing economies of which Ghana is not an exception. Whilst microfinance is not the only economic policy in Ghana aimed at reducing poverty, it is certainly one effective tool amongst many for poverty reduction and eradication. Microfinance as used in this study means the provision of credit, rendering of micro services such as savings, insurance, fund transfer services by microfinance institutions in return for interest income while microcredit is the provision of small amount of loans to the productive poor people to undertake economic activity in return for interest income by the Microfinance Institutions (MFIs).

In Ghana, traditional financial institutions have actually neglected the majority of the population (Aveh, 2011). Considered as high-risk clients by traditional financial institutions, the productive poor have been denied access to financial services. As a result, microfinance has been praised during the last twenty years as a new development policy tool - serving people who have been excluded from the formal banking system (Hudon, 2010).

Davutoğlu (2013) noted that for a very long-time poverty has been the most important problem that urgently needs a sustainable solution for the sake of society's own self-existence. Whether it is conceptualized rural poverty, urban poverty, absolute poverty or relative poverty, millions of people in different parts of the world have to face poverty on a daily basis, which makes the problem a global issue. There have always been attempts, especially from the developed countries, to address the causes and effects of poverty in developing countries. Microfinance institutions (MFIs) have been set up in many countries to play the intermediary role between the suppliers of funds and the poor. The primary objective of these MFIs is poverty eradication by providing financial services to as many productive poor people as possible. However, considering the fact that donor resources are limited, the need has arisen for the microfinance institutions to be financially sustainable. In order to reduce poverty, MFIs must also be profitable because without donor funding profitable operation is the only way to be sustainable. The challenge facing MFIs now is how to lend to a significant number of the productive poor without compromising the need to be viable and sustainable financial institutions (Aveh, 2011).

Similarly, poverty reduction was institutionalized in 1944, with the establishment of the World Bank at the birth of the Bretton Woods system. With the IMF assigned the tasks of stabilizing the world's economy and promoting free trade in the post WW II, the problem of poverty was delegated to the World Bank. The industrial 
nations felt some responsibility for the world's poor; after all, since Africa, Latin America and parts of Asia, had been colonies in European empires and they would need financial support once they gained their independence. The strategy, with the U.S. as leader, was to bring free trade to the developing world with the hope of integrating them into the formal economy (Leikem, 2012).

The government of Ghana has made an effort in using microfinance to eradicate poverty and as a result, a number of ministries, departments and agencies (MDA) have established desks or units for microfinance activities. Among the MDA with microfinance programmes are Ministry of Finance and Economic Planning, Ministry for Gender, Children and Social Protection, Bank of Ghana, Ministry of Local Government and Rural Development. In order to co-ordinate and streamline activities of the industry, a central body, known as the Microfinance and Small Loans Centre (MASLOC) was established in 2006. Its mandate was, and still is, to co-ordinate all microfinance activities in the country especially government programmes and complement the activities of other microfinance apex bodies (Annim, 2011). These institutions collectively have achieved some level of successes in reducing poverty in Ghana.

As part of measures in reducing poverty, MASLOC in 2013 disbursed GH $\notin 3,116,000$ (USD\$890,285.71) and $\mathrm{GH} \notin 163,200$ (USD\$46,628.57) as group and individual loans respectively to the productive poor in different trades in pottery, agricultural production, catering services, and gari processing consisting of 7,400 females and 517 males in the Brong-Ahafo Region of Ghana (MASLOC, 2014). At the time, the exchange rate of the US dollar and the Ghana Cedi was $\$ 1$ to GHф3.50. In the Northern Region, MASLOC presented tricycles to selected youths (productive poor) as part of measures to creating jobs in the transport sector who are expected to work and pay for the cost of the tricycles within one to two years (MASLOC, 2016). MASLOC has offices in all the ten, now sixteen regions of Ghana and has rotated assistance by way of micro loans in all the then ten, and now regions from time to time. However, the major challenge of MASLOC is the recovery of its loans in order to be sustainable. Many of the productive poor feel that it is government money, which makes the operations of the Centre difficult.

\subsection{Objectives of the study}

The objective of this study is to examine the factors influencing sustainability and outreach of MFIs in northern Ghana. In order to achieve this, the following specific objectives are relevant:

1. To examine the relationship between capital structure and financial sustainability of MFIs from the view point of managers and operation staff in northern Ghana

2. To examine the relationship between capital structure and outreach of MFIs from the view point of managers and operation staff in northern Ghana

3. To examine the relationship between financial sustainability and outreach of MFIs from the view point of managers and operation staff in northern Ghana

4. To examine the relationship between capital structure, financial sustainability and outreach of MFIs from the view point of managers and operation staff in northern Ghana

\subsection{Research Questions and Hypotheses}

The main research question is what are the major factors affecting the sustainability and outreach of MFIs in northern Ghana? To answer this question calls for an empirical examination into the major factors affecting the sustainability and outreach of MFIs in northern Ghana.

The research questions and hypotheses for the study are stated below:

\subsubsection{Research Question 1:}

Is there any statistically significant relationship between capital structure and financial sustainability of MFIs from the view point of managers and operation staff in northern Ghana?

H1o: There is no statistically significant relationship between capital structure and financial sustainability of MFIs from the view point of managers and operation staff in northern Ghana

H1a: There is a statistically significant relationship between capital structure and financial sustainability of MFIs from the view point of managers and operation staff in northern Ghana

\subsubsection{Research Question 2:}

Is there any statistically significant relationship between capital structure and outreach of MFIs from the view point of managers and operation staff in northern Ghana?

$\mathrm{H} 2 \mathrm{o}$ : There is no statistically significant relationship between capital structure and outreach of MFIs from the view point of managers and operation staff in northern Ghana

H2a: There is a statistically significant relationship between capital structure and outreach of MFIs from the view point of managers and operation staff in northern Ghana

\subsubsection{Research Question 3:}

Is there any statistically significant relationship between financial sustainability and outreach of MFIs from the view point of managers and operation staff in northern Ghana?

H3o: There is no statistically significant relationship between financial sustainability and outreach of MFIs from 
the view point of managers and operation staff in northern Ghana

H3a: There is a statistically significant relationship between financial sustainability and outreach of MFIs from the view point of managers and operation staff in northern Ghana

\subsubsection{Research Question 4:}

Is there any statistically significant relationship between capital structure, financial sustainability and outreach of MFIs from the view point of managers and operation staff in northern Ghana?

H4o: There is no statistically significant relationship between capital structure, financial sustainability and outreach of MFIs from the view point of managers and operation staff in northern Ghana?

$\mathrm{H} 4 \mathrm{a}$ : There is a statistically significant relationship between capital structure, financial sustainability and outreach of MFIs from the view point of managers and operation staff in northern Ghana?

The rest of the paper is organized as follows: Literature review, methodology, presentation of findings, discussion of results, and conclusions and recommendations.

\section{Theoretical Background and Literature Review}

The following theories were guided by the research paper and empirical literature examined on microfinance sustainability and outreach.

\subsection{Life Cycle Theory}

There are three stages of the cycle namely formative, maturity and final stages. It is the stages of the development process that will determine which funding source becomes available and appropriate. The life cycle theory posits that the sources of financing are directly linked to the development stages of MFIs. As a result, donor grants and soft loans comprise the majority of the funding in the formative stages of the MFIs. However, as the MFI grows into the maturity stage, private debt capital becomes available, but the debt structures have restrictive covenants or guarantees (Bogan, 2012; Omondi, 2014).

At the final stage of the MFI evolution however, traditional equity financing becomes available and preferred funding choice, which allows for stability, increased efficiency and outreach (Bogan, 2011). According to this theory, most MFIs start out as NGOs with a social vision, funding operations with grants and concessional loans from donors and international financial institutions that effectively serve as the primary sources of risk capital for the microfinance sector (Omondi, 2014). The incentives for better financial performance on part of the nonprofit MFIs include attainment of self-sufficiency and reduced reliance on donor funds (Quayes, 2012). Thus, the literature on microfinance devotes considerable attention to this process of "NGO transformation" as a life cycle model outlining the evolution of a microfinance institution (Helms, 2006, 46; Bogan, 2011, p. 1046). Farrington and Abrams (2002) as cited in Omondi (2014) provided empirical evidence in favour of the life cycle theory, by indicating that an increase in competition in MFIs as they increase in number and documenting a spread in regulation facilitating a change in the capital structure of the industry.

\subsection{Profit Incentive Theory or the Institutionist Theory}

The profit-incentive theory or the institutionist theory posits that MFI use of commercial funding sources at any stage of development will enable MFIs to meet the "microfinance promise" (Bogan, 2012, p. 1047). Reliance on commercial funding is beneficial along two dimensions: outreach and efficiency. Since donor funds are limited in amount, reliance on donor funding limits the ability of MFIs to expand to meet rising demand for services. There is also a question as to whether reliance on donor funds allows MFIs to avoid pressures to operate efficiently. Commercially funded MFIs respond to the profit incentive, working to increase revenues and decrease expenses so that they can have revenues sufficient to cover all operating expenses (Bogan, 2012). Additionally, the profit incentive theory focus on building sound and sustainable financial organizations that can provide financial service to more poor people for longer period of time (Adhikary \& Papachristou, 2014). Morduch (2000, p. 619) characterizes the debate between the profit incentive and welfare approach as "microfinance schism".

However, recent emphasis on attainment of financial self-sufficiency has created some apprehension in the microcredit industry, that it may adversely affect the mission of social outreach of providing credit access to the poor (Quayes, 2012), which is why opponents are very critical of this theory. Therefore, there has been a recent paradigm shift in the microcredit industry, from subsidised credit delivery programmes to financially selfsufficient institutions providing commercial microfinance (Quayes, 2012).

\subsection{Welfare Theories}

The welfare approach to evaluating MFIs sustainability is based on MFIs contribution to social welfare of the greater number of the poor people. Welfarists argue that MFIs should focus on providing financial services to the poorest households in an attempt to reducing poverty rather than being too focused on financially self-sustanable (Adhikary \& Papachristou, 2014). The mission of MFIs according to supporters of this approach is to have positive social impact on their clients that is the poor. Advocators of welfare approach advocate that there is trade-off 
between financial sustainability and outreach, which jeopardise the main MFIs mission: mission drift. MFIs seeking financial sustainability will favour financial performance instead of targeting poor clients (Nurmakhanova, Kretzschmar \& Fedhila, 2015).

The danger as pointed out by Hermes et al. (2011) is that while targeting profitability, MFIs will focus on wealthier borrowers at the expense of poorer ones who are costly and riskier to be financially served. In line with this theory, Nyamsogoro (2010) indicates that MFIs should serve many clients possible even when it may appear not to be profitable, and that the deficit if any in operations, should be covered by donor and government support or social investors. Generally speaking, providing small loans at affordable interest rates, focusing more on women loan clients, emphasizing operations in rural areas and adopting group-based lending methodology were the original social missions of microfinance (Kar, 2013), which were aimed at reducing poverty amongst the poor in society and that is the main aim of this theory.

\subsection{Review of Empirical Evidence of Factors Influencing MFIs Sustainability and Outreach}

There is recent research on the factors affecting the sustainability and outreach of MFIs around the world in particular the developing world where poverty is wide and deep. Bogan (2012) conducted a study across Africa, East Asia, Eastern Europe, Latin America, the Middle East, and South Asia for the years 2003 and 2006. The MFI data were collected from individual institutions as reported to MIX Market and found that the size of an MFI's assets and an MFI's capital structure are associated with performance. Additionally, Bogan (2012) indicates that for MFIs, asset size does matter in terms of both sustainability and outreach. He further uncovered that grants as a percentage of assets is significant and negatively related to sustainability but is positively related to MFI cost per borrower. Conclusively, Bogan (2012) found causal evidence to support the assertion that the use of grants drives down operational self-sufficiency as funding source for MFIs. These findings thus suggest that a well-established MFI is most likely to have a better asset backing than a relatively younger MFI. This outcome is consistent to a similar study by Bogan et al. (2007) and Bogan (2009).

Kimando, Kihoro and Njogu (2012) conducted a study on the factors influencing the sustainability of MFIs in the Muranga Municipality in Kenya. The sample size was 45 respondents who were managers of the 15 MFIs in the Muranga Municipality and 2 field officers from every MFI. The study found that financial regulation, number of clients served, financial coverage and volume of credit transacted were the determining factors that influenced the sustainability of MFIs. Kiphoech and Muturi (2014) studied the determinants of financial performance of MFIs in Kenya. They used 52 respondents from selected MFIs in Nakura town in Kenya. The study used both qualitative and quantitative research approaches using descriptive research design. The authors found that the number of borrowers, capital adequacy and branch network had the greatest influence on the performance of MFIs.

Researchers such as Pati (2012), Mersland and Strom (2009), Cull et al. (2007), Honohan (2004), Ayayi and Sene (2010), and Ngo et al. (2014) have used other micro-institutional variables such as firm size, expenditure control, mode of governance of MFIs and loan portfolio status to explain financial sustainability. Nurmakhanova, Kretzschmar, and Fedhila (2015) examined the trade-off between financial sustainability and outreach of MFIs using data set comprised of 1347 observations for 450 MFIs across 71 countries over a period 2006-2008. The authors found that MFIs focusing on financial sustainability did not hurt the depth and breadth of outreach. Based on their findings, they indicate that a win-win proposition for MFIs is achievable. Additionally, the authors also uncovered that the age of MFI positively affects financial sustainability, which indicates that as MFIs mature, they become much more efficient and operate at a lower cost. The author's findings are consistent with Caudill et al. (2009) who uncovered that generally MFIs operate with lower costs the longer they are in operation, which in turn improves their efficiency. On the one hand, the outcome of this study contradicts the findings of Kar (2012) and Bogan (2012) who both uncovered a positive effect of leverage on financial performance of MFIs. Nurmakhanova, Kretzschmar, and Fedhila (2015) found that there is a negative relationship between leverage and financial sustainability of MFIs.

Kipesha and Zhang (2013) conducted a study in order to examine the tradeoffs between sustainability, profitability and outreach using a panel data of 47 MFIs for four-year period from 2008-2011. The data for their study was obtained from mix market data using unbalanced panel regression analysis model. Using the welfare approach, Kipesha and Zhang (2013) uncovered the presence of negative tradeoffs between profitability and outreach to the productive poor and did not show presence of tradeoffs between financial sustainability and outreach measures (Gashayie \& Singh, 2015). However, under the profit incentive approach, the study by Kipesha and Zhang (2013) found that outreach to the productive poor had a positive relationship with both sustainability and profitability measures. The authors concluded that the possibility of tradeoffs exists between outreach to the productive poor with profitability measures as compared to the outreach with financial sustainability and recommended that MFIs in East Africa should concentrate on financial sustainability in order to reduce their subsidy dependence, ensure survival and growth in the future.

In India, Zerai and Rani (2012) conducted a study on the tradeoff between outreach and sustainability of MFIs 
using correlation matrix on 85 Indian MFIs. The data for the study was obtained from the Mix Market and found that correlation (from weak to strong) between outreach and financial sustainability. The authors indicated that outreach and sustainability were supplementing each other this is because the study failed to establish a tradeoff between outreach and financial sustainability. Conversely, the study of Quayes (2012) on the depth of outreach and financial sustainability of MFIs found positive complementary relationship between financial sustainability and depth of outreach. The study used data from 702 MFIs accessed from Mix market operating in 83 different countries. This finding thus contradicted that of Zerai and Rani (2012) and supported that of Kipesha and Zhang (2013) and Nurmakhanova, Kretzschmar, and Fedhila (2015).

Sekabira (2013) noted in a study conducted on the role of capital structure on the performance of MFIs in Uganda that grants and debt had a substantial damaging consequence on MFI performance and concludes that debt and grants were negatively correlated to operational and financial sustainability. He used panel data from 14 MFIs in Uganda. The author recommends that MFIs must reduce dependence on debts and grants and resort to accumulating share capital for long-term financial sustainability. Similarly, Kinde (2012) conducted a study in order to identify factors affecting financial sustainability of MFIs in Ethiopia. He used multivariate regression model (known as ordinary least square) on balanced panel data set of 126 observations from 14 MFIs between the periods of 2002 to 2010 from mix market. Kinde (2012) uncovered that microfinance breadth of outreach, depth of outreach, dependency ratio and cost per borrower affect significantly, but capital structure and staff productivity has insignificant impact on financial sustainability of MFIs in Ethiopia. Consequently, the researcher recommends further study in this area in order to consider geographical location, growth stages, ownership, age, MFIs product deliver methodology and dimensions of sustainability.

Anim (2010) conducted a study on the institutional performance and outreach in Ghana. The study used micro level data from households in Ghana and cross-country data from the Mix Information Exchange (MIX). Varied micro econometric techniques such as ordinary least squares, instrumental variable estimation, quartile regression, pooled regression were used and found that there exists trade-off between financial sustainability and reaching the poorer clients. Additionally, the study uncovered those formal MFIs dispensing their own funds targeted poorer clients. Consequently, the study recommended among others that management of MFIs and stakeholders must work together to harmonize microfinance programmes regardless of their funding structure. However, this study is different in that the respondents are the managers and staff of MFIs in northern Ghana, whereas Annim (2010) targeted at poorer households in Ghana.

Aveh (2011) noted in a study conducted into the factors that influence sustainability and success of MFIs in Ghana. The study used 114 questionnaires and 14 face-to face interviews. The data was analysed using descriptive statistics, cross-tabulation and regression analysis. The study found that business strategy, governance, institutional characteristics, agency cost had positive relationship with MFIs sustainability in Ghana. This study was limited because of the sample size of 14 MFIs of which majority were located at the southern part of Ghana. MFIs located in northern Ghana where poverty is much wide and deep had very limited coverage.

Studying the microfinance literature indicates that there is vast empirical evidence all over the world on the factors that affects MFIs sustainability and outreach. The literature also indicates that several factors affect MFIs sustainability and outreach. However, in the case of Ghana there is very limited literature on this subject area. In the case of northern Ghana and to the best of my knowledge there is no such published study specifically other than impact assessment studies. Therefore, this study in bridging this research gap and to provide empirical evidence on factors influencing the sustainability of MFIs in northern Ghana.

\section{Research Methodology}

This study employed use of the quantitative method. The reason for the quantitative method is that it allowed the researchers to test the relationship between some factors and variables in a situation (Bryman \& Bell, 2003). This study was facilitated by the use of primary data. Primary data was collected from 181 managers and the operations staff of the MFIs studied using a structured questionnaire.

The questionnaires sufficiently address the objectives of the study. This study employed a descriptive survey technique. Descriptive survey technique is preferred because it is used to obtain information concerning the current status of a phenomena and purposes of these methods is to describe "what exists" with respect to situational variables in order to explain the relationship between and among variables (Kimando, Kihoro, \& Njogu, 2012). This method is very suitable for the gathering and collection of board data.

The population of the study comprised of 360 managers and staff of all the MFIs registered and currently operating in northern Ghana. Northern Ghana is made up of three regions namely Upper East Region, Upper West Region and Northern Region. However, sampling techniques such as purposive and convenience was used in order to select 189 respondents for the study. "A sample size is a set drawn from the population", (Keller, 2009, p.5). Thus, the sample size for this study was determined using formula for sample size determination by Adanza (1995). That is: $\mathrm{n}=\frac{N}{1+N e^{2}}$ 
Where: $\mathrm{n}=$ sample size, $\mathrm{N}=$ total population, $\mathrm{e}=$ margin of error; $\mathrm{n}=360 / 1+(0.05) 2(360)=189$, therefore, a minimum of about 189 respondents is desired for this study. In this regard, the study comprised of a sample of at least 189 respondents for the study made of managers and operations staff of MFIs in northern Ghana.

The questionnaires were distributed to respondents through personal meetings with all managers and staff in all MFIs that were studied across the three northern regions of Ghana. The study employed the services of two research assistants in the data collection process. The services of the research assistants were fully budgeted for. These research assistants were adequately trained before and during the data collection process. Data collected was analyzed via Statistical Package for Social Sciences (SPSS) software. This package is widely known and accepted for its ability to handle large amounts of data and efficiency. Data was presented using tables with various affiliations such as genders, frequency, percentages, mean and standard deviation among others.

\section{Analysis and Presentation of Results}

This section of the research paper analyses and present the results.

\subsection{Demographic Statistics}

The questionnaires were administered to managers and selected operation staff of MFIs in the five northern regions of Ghana namely Northern Region, Upper East Region, Upper West Region, Savannah and North East Regions. Overall, 18 MFIs were studied across the five regions. A total of 189 questionnaires were sent to the managers and selected operation staff of 18 MFIs in northern Ghana and 181 were correctly completed and retrieved from the respondents representing $95.8 \%$.

Table 1 shows the demographic profiles of respondents. The respondents consist of male $120(66.3 \%)$ and female $61(33.7 \%)$. The majority of the respondents are between the ages of 26-35, which represented $61.3 \%$. Only $4(2.3 \%)$ of the respondents are between the ages of 46-55 years. Most of the respondents $85(47.0 \%)$ are firstdegree holders. This is closely followed by diploma holders 61 (33.7\%). Put together first degree and diploma holders constituted $80.7 \%$ of the respondents. Professional, masters and $\mathrm{PhD}$ qualification holders constituted only $5 \%$. The educational background, professional qualification, and the relatively young age indicate that the respondents would have a collective perspective on the issues relating to the factors influencing the sustainability and outreach of MFIs in northern Ghana.

Table 1

Demographic profiles of respondents

\begin{tabular}{llll}
\hline Demographic Item & Categories & Frequency & Percent \\
\hline \multirow{3}{*}{ Gender } & Male & 120 & 66.3 \\
& Female & 61 & 33.7 \\
& Total & 181 & 100.0 \\
Age & $18-25$ years & 30 & 16.6 \\
& 26-35years & 111 & 61.3 \\
& 36-45years & 36 & 19.9 \\
& 46-55years & 4 & 2.3 \\
Highest educational level & Total & 181 & 100.0 \\
attained & High School & 26 & 14.4 \\
& Diploma & 61 & 33.7 \\
& Profee & 85 & 47.0 \\
& Doctorate & 8 & 4.4 \\
\hline
\end{tabular}

4.2 Relationship between capital structure and financial sustainability of MFIs in northern Ghana

In order to examine the relationship between capital structure and financial sustainability as indicated in the research question above, the study used multiple regression analysis. This analysis technique was necessary in testing for the acceptance or the rejection of hypotheses H1o and H1a. In this analysis, there is always the possibility of correlation among the independent variables. As a result, the multiple correlation results are shown in Table 2. 
Table 2

Correlations between Capital Structure and Financial Sustainability of MFIs in Northern Ghana

\begin{tabular}{lllllllllllll}
\hline & CO1 & CO2 & CO3 & CO4 & CO5 & CO6 & CO7 & CO8 & CO9 & CO10 & CO11 & CO12 \\
\hline CO1 & 1.00 & & & & & & & & & & & \\
CO2 & 0.50 & 1.00 & & & & & & & & & \\
CO3 & 0.44 & 0.56 & 1.00 & & & & & & & & \\
CO4 & 0.23 & 0.39 & 0.44 & 1.00 & & & & & & & \\
CO5 & 0.13 & 0.19 & 0.21 & 0.22 & 1.00 & & & & & & \\
CO6 & 0.42 & 0.42 & 0.52 & 0.27 & 0.30 & 1.00 & & & & & & \\
CO7 & 0.42 & 0.31 & 0.29 & 0.21 & 0.03 & 0.42 & 1.00 & & & & & \\
CO8 & 0.30 & 0.26 & 0.27 & 0.25 & 0.18 & 0.36 & 0.31 & 1.00 & & & & \\
CO9 & 0.20 & 0.25 & 0.12 & 0.07 & 0.23 & 0.18 & 0.15 & 0.40 & 1.00 & & & \\
CO10 & 0.13 & 0.25 & 0.20 & 0.17 & 0.01 & 0.13 & 0.05 & 0.12 & 0.25 & 1.00 & & \\
CO11 & 0.08 & 0.12 & 0.00 & 0.03 & 0.20 & 0.10 & 0.06 & 0.08 & 0.17 & 0.11 & 1.00 & \\
CO12 & -0.02 & 0.07 & -0.02 & 0.05 & 0.04 & -0.07 & -0.08 & 0.00 & 0.04 & -0.08 & 0.24 & 1.00 \\
CO13 & 0.23 & 0.16 & 0.13 & 0.03 & -0.06 & 0.18 & 0.28 & 0.18 & 0.27 & 0.02 & 0.00 & 0.07 \\
CO14 & 0.00 & 0.11 & 0.06 & -0.05 & -0.09 & 0.04 & 0.08 & 0.03 & 0.10 & 0.18 & 0.01 & 0.16 \\
CO15 & -0.03 & 0.12 & 0.10 & 0.00 & -0.07 & 0.12 & 0.16 & 0.08 & 0.10 & 0.02 & 0.02 & 0.15 \\
CO16 & -0.04 & -0.13 & -0.04 & 0.08 & 0.06 & -0.01 & 0.01 & 0.03 & 0.15 & -0.05 & -0.06 & 0.26 \\
CO17 & 0.37 & 0.26 & 0.30 & 0.12 & 0.16 & 0.30 & 0.36 & 0.13 & 0.23 & 0.16 & -0.08 & -0.14 \\
CO18 & 0.45 & 0.34 & 0.38 & 0.28 & 0.09 & 0.33 & 0.33 & 0.13 & 0.12 & 0.03 & -0.10 & -0.02 \\
CO19 & 0.22 & 0.26 & 0.34 & 0.28 & 0.26 & 0.38 & 0.12 & 0.18 & 0.09 & 0.03 & 0.16 & 0.11 \\
Financial & & & & & & & & & & & & -0.03 \\
Sustainability & 0.47 & 0.39 & 0.46 & 0.30 & 0.23 & 0.45 & 0.37 & 0.20 & 0.20 & 0.11 & -0.01 & -0.03 \\
\hline
\end{tabular}

Table 2 continued on next page.

Table 2 continued from previous page

\begin{tabular}{lllllllll}
\hline \multicolumn{1}{c}{ CO13 } & CO14 & CO15 & CO16 & CO17 & CO18 & CO19 & Capital Structure \\
\hline CO12 & & & & & & & & \\
CO13 & 1.00 & & & & & & & \\
CO14 & 0.36 & 1.00 & & & & & & \\
CO15 & 0.39 & 0.58 & 1.00 & & & & & \\
CO16 & 0.10 & 0.20 & 0.16 & 1.00 & & & & \\
CO17 & 0.28 & 0.08 & 0.01 & 0.03 & 1.00 & & & \\
CO18 & 0.15 & -0.02 & 0.05 & 0.11 & 0.42 & 1.00 & & \\
CO19 & 0.12 & -0.08 & -0.04 & 0.06 & 0.17 & 0.36 & 1.00 & \\
Financial Sustainability & 0.25 & -0.01 & 0.01 & 0.09 & 0.73 & 0.80 & 0.68 & 1
\end{tabular}

The results in Table 2 indicate a positive relationship between capital structure and financial sustainability from the point of view of managers and operation staff who were surveyed. However, at this stage it was not possible to conclude that any of these correlations are important until a test for significance was performed in order to accept or reject H1o or H1a. Calculating the test statistic for each of the pair-wise correlations below, we can confirm using summary statistics in Table 3 and analysis of variance Table 4.

From Table 3, the multiple correlation coefficient is 0.607 . This is an indication that the correlation among the independent variable (capital structure) and the dependent variable (financial sustainability) is positive. The coefficient of determination, R-square, is $36.92 \%$. This implies that close to $37 \%$ of the variation in the dependent variable (financial sustainability) is explained by the independent variable (capital structure). The regression statistics determines the degree to which local financial experts believe that capital structure of MFIs in northern Ghana is explained by financial sustainability. This was very relevant because there was more than one predictor variable.

Table 3

Regression Statistics between Capital Structure and Financial Sustainability of MFIs in Northern Ghana

\begin{tabular}{ll} 
Multiple R & 0.608 \\
R Square & 0.369 \\
Adjusted R Square & 0.365 \\
Standard Error & 0.369 \\
Observations & 181. \\
\hline
\end{tabular}

The adjusted R-square, which is a measure of the explanatory power, is 0.3645 . However, this statistic is not generally interpreted because it is neither a percentage (like the R-square), nor a test of significance (such as the F-statistic).

The analysis of variance is shown in Table 4. The analysis of variance information provides the breakdown 
of the total variation of the dependent variable in this case (financial sustainability) in to the explained and unexplained portions. The significance level of $\alpha=0.05>0.0000$ indicating that there is a statistically significant relationship between capital structure and financial sustainability in the opinion of the managers and operation staff of MFIs surveyed in northern Ghana. F (179) $=104.7$, SS Regression is the variation explained by the regression line; SS Residual is the variation of the dependent variable (financial sustainability) that is not explained.

Table 4

Analysis of Variance (ANOVA) of Capital Structure of MFIs in Northern Ghana

\begin{tabular}{llllll}
\hline & $D f$ & $S S$ & $M S$ & $F$ & Significance- $F$ \\
\hline Regression & 1 & 14.2596 & 14.2596 & 104.7118 & 0.0000 \\
Residual & 179 & 24.3762 & 0.1362 & & \\
Total & 180 & 38.6358 & & & \\
\hline
\end{tabular}

Table 5 is the coefficient or p-value results. From the table, we can see that the p-value is the same as the significant value in Table 5. At $\alpha=0.05>0.0000$, and the coefficient is 0.60 .

Table 5

Coefficient of Capital Structure of MFIs in Northern Ghana

\begin{tabular}{lllll}
\hline & Coefficients & Standard Error & t-Stat & P-value \\
\hline Intercept & 1.4384 & 0.2166 & 6.6399 & 0.0000 \\
Capital Structure & 0.5988 & 0.0585 & 10.2329 & 0.0000 \\
\hline
\end{tabular}

Based on the results above, the study failed to reject the alternative hypothesis (H1a) that there is a statistically significant relationship between capital structure and financial sustainability from the view point of managers and operation staff of MFIs surveyed in northern Ghana in favor of the null hypothesis (H1o), which stated that there is no statistically significant relationship between capital structure and financial sustainability from the view point of managers and operation staff of MFIs surveyed in northern Ghana.

The practical implications of the results above mean that if an MFI structured its capital structured properly, for example, having clear equity owners coupled with proper financial constraints management by the leadership of the firm, financial experts believe it will result in the significant improvement of financial sustainability of MFIs operations in northern Ghana. Similarly, the outcome above suggests that equity capital should constitute the greater proportion of capital structure mixed of MFIs in northern Ghana in the views of the respondents.

The capital structure of MFIs in this study is assumed to consist of equity capital, debt capital, and donor funding. Overall, the study has uncovered a statistically significant positive relationship between capital structure and financial sustainability in the view of managers and operation staff of MFIs surveyed in northern Ghana. Therefore, the null hypothesis (H1o) is rejected while the alternative hypothesis (H1a) is accepted. The practical implications of the above findings mean that if an MFI's capital structure is properly well formulated such as having clear equity owners coupled with professional management of its financial constraints by the leadership of the MFI, financial experts believe it will result in improvement in financial sustainability which consequently will be reflected in the MFIs ability to pay its debt and continue to operate without operational challenges. This also implies that financial experts believe that MFI will generate sufficient revenue to cover all its expenses, increase deposits from the productive poor and will be able to access commercial debts at competitive costs thereby contributing significantly to financial sustainability.

\subsection{Relationship between Capital Structure and Outreach of MFIs in northern Ghana}

In order to achieve the second objective of examining the relationship between capital structure and outreach of MFIs in northern Ghana, Spearman correlation was computed. The use of this analysis technique was necessary in testing for hypotheses H2o and H2a. Table 28 indicates low correlations between capital structure and outreach from the point of view of managers and operation staff surveyed among MFIs in northern Ghana. 
Table 6

Correlations between Capital Structure and Outreach of MFIs in Northern Ghana

\begin{tabular}{llllllllllll} 
& $C F S$ & $C F S$ & $C F S$ & $C F S$ & $C F S$ & $C F S$ & $C F S$ & $C F S$ & $C F S$ & $C F S 1$ & $C F S 1$ \\
& 1 & 2 & 3 & 4 & 5 & 6 & 7 & 8 & 9 & 0 & 1 \\
\hline CFS1 & 1 & & & & & & & & & & \\
CFS2 & 0.13 & 1.00 & & & & & & & & & \\
CFS3 & 0.28 & 0.17 & 1.00 & & & & & & & & \\
CFS4 & 0.16 & -0.04 & 0.34 & 1.00 & & & & & & & \\
CFS5 & 0.03 & 0.00 & 0.28 & 0.22 & 1.00 & & & & & & \\
CFS6 & -0.07 & 0.26 & -0.11 & -0.11 & 0.11 & 1.00 & & & & & \\
CFS7 & 0.20 & 0.16 & 0.18 & 0.03 & 0.14 & 0.18 & 1.00 & & & & \\
CFS8 & 0.05 & -0.02 & -0.10 & -0.02 & -0.26 & -0.01 & 0.02 & 1.00 & & & \\
CFS9 & 0.04 & 0.28 & 0.02 & -0.25 & 0.00 & 0.26 & 0.11 & -0.15 & 1.00 & & \\
CFS10 & 0.11 & 0.17 & 0.12 & 0.09 & 0.06 & -0.05 & 0.15 & 0.11 & 0.06 & 1.00 & \\
CFS11 & 0.17 & 0.15 & 0.12 & 0.10 & 0.04 & -0.06 & 0.18 & 0.15 & 0.05 & 0.84 & 1.00 \\
CFS12 & 0.06 & 0.12 & 0.12 & 0.11 & 0.05 & -0.05 & 0.16 & 0.21 & 0.00 & 0.75 & 0.87 \\
CFS13 & 0.08 & 0.13 & 0.06 & 0.16 & 0.06 & 0.07 & 0.20 & 0.20 & 0.05 & 0.56 & 0.64 \\
CFS14 & 0.07 & -0.01 & -0.07 & 0.11 & -0.01 & 0.00 & 0.16 & 0.18 & 0.08 & 0.41 & 0.46 \\
CFS15 & -0.03 & 0.16 & 0.07 & -0.06 & 0.19 & 0.29 & 0.10 & -0.21 & 0.35 & 0.06 & 0.00 \\
CFS16 & 0.19 & -0.01 & 0.13 & 0.21 & -0.08 & -0.02 & 0.17 & 0.04 & -0.08 & 0.32 & 0.35 \\
CFS17 & 0.20 & 0.02 & 0.24 & 0.25 & -0.02 & -0.02 & 0.27 & 0.10 & 0.02 & 0.29 & 0.30 \\
CFS18 & -0.04 & 0.11 & -0.13 & -0.07 & 0.00 & 0.30 & 0.26 & 0.20 & 0.23 & 0.20 & 0.26 \\
CFS19 & 0.18 & 0.09 & 0.02 & 0.29 & -0.09 & -0.02 & 0.25 & 0.13 & -0.04 & 0.18 & 0.28 \\
CFS20 & 0.21 & 0.10 & -0.01 & -0.09 & -0.05 & 0.13 & 0.10 & 0.19 & 0.16 & 0.24 & 0.26 \\
CFS21 & 0.24 & 0.15 & 0.02 & -0.01 & -0.01 & 0.06 & 0.10 & 0.14 & 0.19 & 0.18 & 0.28 \\
CFS22 & 0.16 & 0.14 & -0.05 & 0.04 & 0.05 & 0.01 & 0.13 & 0.20 & 0.15 & 0.34 & 0.38 \\
OUTREAC & & & & & & & & & & & 0.06 \\
H & -0.05 & 0.05 & -0.05 & 0.04 & -0.01 & 0.18 & 0.23 & 0.08 & 0.15 & 0.02 & 0.06 \\
\hline Table 6 & & & & & & & & &
\end{tabular}

Table 6 continued on next page.

Table 6 continued from previous page

\begin{tabular}{|c|c|c|c|c|c|c|c|c|c|c|c|}
\hline & $\begin{array}{l}\text { CFS1 } \\
2\end{array}$ & $\begin{array}{l}\text { CFS1 } \\
3\end{array}$ & $\begin{array}{l}\text { CFS1 } \\
4\end{array}$ & $\begin{array}{l}\text { CFS1 } \\
5\end{array}$ & $\begin{array}{l}\text { CFS1 } \\
6\end{array}$ & $\begin{array}{l}\text { CFS1 } \\
7\end{array}$ & $\begin{array}{l}\text { CFS1 } \\
8\end{array}$ & $\begin{array}{l}\text { CFS1 } \\
9\end{array}$ & $\begin{array}{l}C F S 2 \\
0\end{array}$ & $\begin{array}{l}C F S 2 \\
1\end{array}$ & $\begin{array}{l}C F S 2 \\
2\end{array}$ \\
\hline \multicolumn{12}{|l|}{ CFS11 } \\
\hline CFS12 & 1.00 & & & & & & & & & & \\
\hline CFS13 & 0.73 & 1.00 & & & & & & & & & \\
\hline CFS14 & 0.52 & 0.68 & 1.00 & & & & & & & & \\
\hline CFS15 & 0.02 & 0.02 & -0.07 & 1.00 & & & & & & & \\
\hline CFS16 & 0.32 & 0.28 & 0.21 & -0.15 & 1.00 & & & & & & \\
\hline CFS17 & 0.28 & 0.25 & 0.24 & 0.01 & 0.46 & 1.00 & & & & & \\
\hline CFS18 & 0.28 & 0.39 & 0.30 & 0.27 & 0.15 & 0.19 & 1.00 & & & & \\
\hline CFS19 & 0.29 & 0.35 & 0.30 & 0.00 & 0.26 & 0.45 & 0.25 & 1.00 & & & \\
\hline CFS20 & 0.23 & 0.22 & 0.19 & 0.10 & 0.09 & 0.13 & 0.26 & 0.11 & 1.00 & & \\
\hline CFS21 & 0.25 & 0.21 & 0.20 & 0.05 & 0.17 & 0.18 & 0.20 & 0.14 & 0.64 & 1.00 & \\
\hline CFS22 & 0.38 & 0.39 & 0.35 & 0.05 & 0.20 & 0.11 & 0.42 & 0.29 & 0.35 & 0.48 & 1.00 \\
\hline \multicolumn{12}{|l|}{ OUTREAC } \\
\hline $\mathrm{H}$ & 0.08 & 0.13 & 0.19 & 0.19 & 0.07 & 0.07 & 0.31 & 0.09 & 0.12 & 0.19 & 0.21 \\
\hline
\end{tabular}

This apparent low correlation cannot be confirmed until the analysis of the test-statistics. From the ANOVA

Table 7, $\alpha=0.05<0.07$ This shows that statistically this is insignificant at $95 \%$ confidence level. Therefore, there is no statistically significant relationship between capital structure and outreach in the views of respondents regarding capital structure (independent variable) and outreach (dependent variable) of MFIs in northern Ghana. In other words, the test of significance failed to confirm existence of any correlations in the views of the respondents.

Based on the above results, the study failed to accept the alternative hypothesis (H2a), which states, "there is a statistically significant relationship between capital structure and outreach from the point of view of managers and operation staff of MFIs in northern Ghana" in favor of the null hypothesis (H2o), which stated, "there is no statistically significant relationship between capital structure and outreach from the point of view of managers and operation staff of MFIs in northern Ghana". 
.

|P.

Table 7

Analysis of Variance (ANOVA) of Capital Structure of MFIs in Northern Ghana

\begin{tabular}{llllll}
\hline & $D f$ & $S S$ & $M S$ & $F$ & Significance $F$ \\
\hline Regression & 1.0 & 5.9461 & 5.9461 & 15.9361 & 0.0701 \\
Residual & 179.0 & 66.7889 & 0.3731 & & \\
Total & 180.0 & 72.7351 & & & \\
\hline
\end{tabular}

Relationship between Financial Sustainability and Outreach of MFIs in northern Ghana

Objective 3 of the study was to examine the relationship between financial sustainability and outreach from the point of view of managers and operation staff of MFIs in northern Ghana. Again, in doing so Spearman multiple correlations were used. Tables 8 are correlations among the variables. At this stage like before, we are unable to conclude on the existence of any correlations until analysis of variance.

Table 8

Correlations between Financial Sustainability and Outreach of MFIs in Northern Ghana

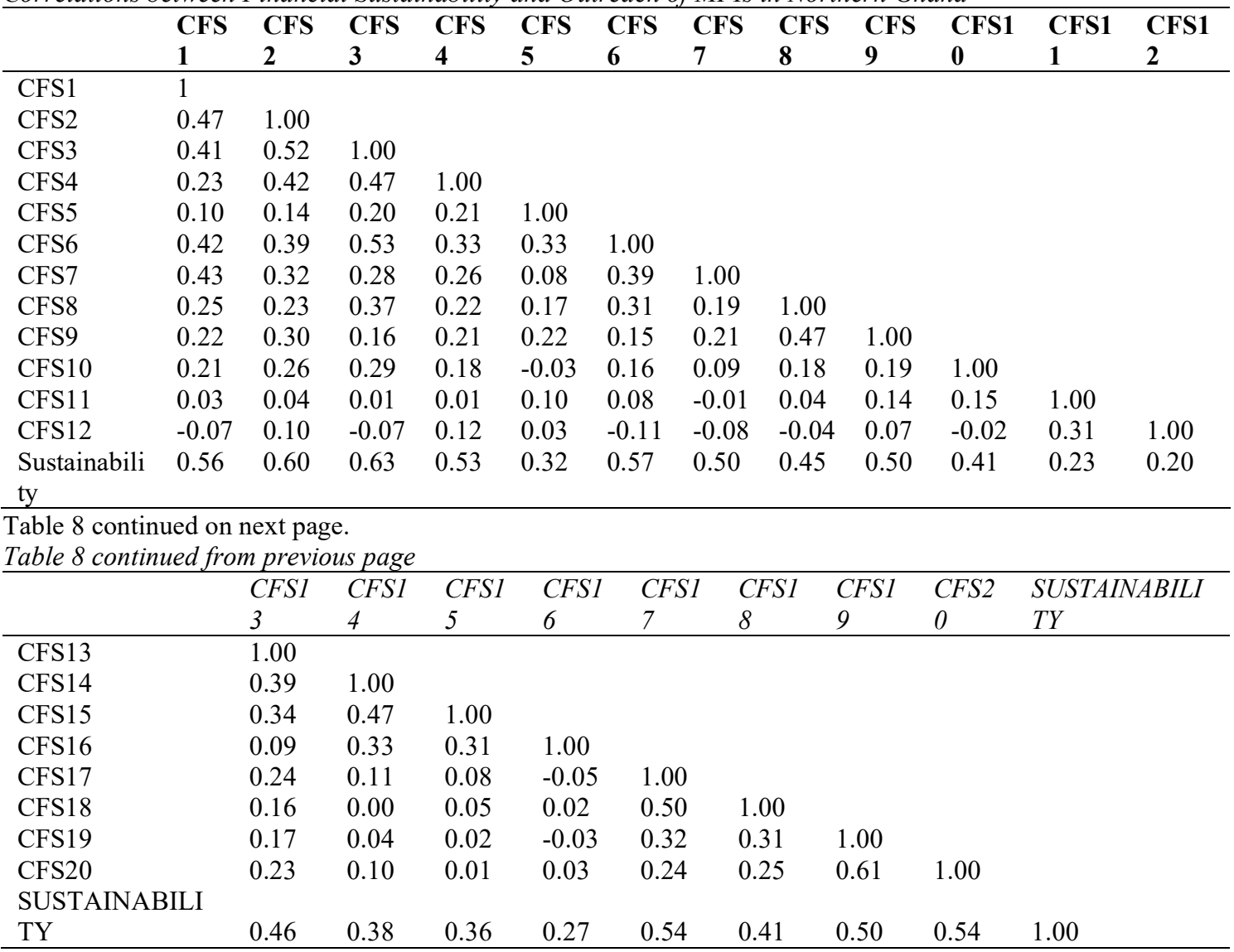

From the Table $9, \alpha=0.05<0.211$. This shows that, statistically this is insignificant at $95 \%$ confidence level. Therefore, there is no statistically significant relationship between financial sustainability (independent variable) and outreach (dependent variable) from the point of view of managers and operation staff of MFIs surveyed in northern Ghana. In other words, the test of significance failed to confirm existence of any correlations. Table 9

Analysis of Variance (ANOVA) of Financial Sustainability of MFIs in Northern Ghana

\begin{tabular}{llllll}
\hline & $D f$ & $S S$ & $M S$ & $F$ & Significance $F$ \\
\hline Regression & 1 & 0.016133 & 0.016133 & 1.5743 & 0.2112 \\
Residual & 179 & 1.834359 & 0.010248 & & \\
\hline Total & 180 & 1.850493 & &
\end{tabular}

The practical implication is that MFIs may be able to cover the loan write-offs, have their retained earning's rising every year but at a marginal rate as well as reducing default rates also marginally which leaves no room for the MFIs to increase the level of outreach both with respect to depth and breadth. In addition, this also means that, in the view of microfinance experts if MFIs has a wider capital base and always maintained higher working capital 
(more current assets compare with current liabilities), possibly they would be able to provide funds to the productive poor on a sustained basis. However, the result here suggest that the current assets are almost the same as current liability or marginally higher than the current liability and as such MFIs are not able to increase the level of outreach in the view of the respondents. As such, MFIs may just meet their cost of operations and remain in business but has no impacts on the level of outreach.

Based on the above results, the study failed to accept the alternative hypothesis (H3a), which states, "there is a statistically significant relationship between financial sustainability and outreach of MFIs from the view point of managers and operation staff in northern Ghana" in favor of the null hypothesis $(\mathrm{H} 3 \mathrm{o})$, which indicated that there is a relationship between financial sustainability and outreach of MFIs from the view point of managers and operation staff in northern Ghana.

\subsection{Relationship between Capital Structure, Financial Sustainability, and Outreach of MFIs in Northern Ghana}

Furthermore, to examine the relationship between capital structure, financial sustainability, and outreach, Spearman multiple correlations were used. This analysis technique was necessary in the testing for the acceptance or rejection of hypotheses $\mathrm{H} 4 \mathrm{o}$ or $\mathrm{H} 4 \mathrm{a}$. Table 10 shows that there is a positive significant relationship between capital structure, financial sustainability, and outreach from the point of view of managers and operation staff of MFIs surveyed in northern Ghana. From Table 10, correlation between capital structure and financial sustainability is 0.609 whilst a correlation between capital structure and outreach is 0.099 .

Table 10

Correlation between Capital Structure, Financial Sustainability and Outreach of MFIs in Northern Ghana

\begin{tabular}{llll}
\hline & Outreach & Sustainability & Capital Structure \\
\hline Outreach & 1 & & \\
Sustainability & 0.09337216 & 1 & 1 \\
Capital Structure & 0.099121892 & 0.607518026 & 1 \\
\hline
\end{tabular}

Consequently, the coefficient of determination R-square indicates a score of 0.371 . This implies that $37.1 \%$ of changes in the respondents' views about financial sustainability and outreach variables (dependent variables) can be explained by the independent variable (capital structure). This is shown in Table 11.

Table 11

Regression Statistics between Capital Structure, Financial Sustainability and Outreach of MFIs in Northern Ghana

\begin{tabular}{ll}
\hline Multiple R & 0.609 \\
R Square & 0.371 \\
Adjusted R Square & 0.364 \\
Standard Error & 0.375 \\
Observations & 181.000 \\
\hline
\end{tabular}

An analysis of variance in Table 12 provides information on the breakdown of the total variations of the dependent variables, which are financial sustainability and outreach into the explained portions.

Table 12

Analysis of Variance (ANOVA) of Capital Structure of MFIs in Northern Ghana

\begin{tabular}{llllll}
\hline & $D f$ & $S S$ & $M S$ & $F$ & Significance F \\
\hline Regression & 2.000 & 14.749 & 7.374 & 52.470 & 0.000 \\
Residual & 178.000 & 25.017 & 0.141 & & \\
Total & 180.000 & 39.765 & & & \\
\hline
\end{tabular}

From Table 12, we can confirm that there is a statistically significant positive relationship existing between the dependent variables, which are financial sustainability and outreach in the views of managers and operation staff of MFIs surveyed in northern Ghana, and that of the independent variable (capital structure). This is because the significance level is at $\alpha=0.05>0.0000$. This indicates a very strong positive relationship of the variables examined in the view of respondents.

Practically, this implies that, in the view of respondents an MFI which has equity owners coupled with professional management of financial constraints by the leadership of an MFI will result in increased deposit mobilization off productive clients, increase profitability, increase liquidity ratios, increase working capital and be able to borrow and pay debts at affordable costs which will consequently result in an improvement in financial sustainability and outreach levels thereby fulfilling the mission of MFIs in reducing poverty and improving the livelihood of the productive poor.

Based on the results above, the study failed to accept the null hypothesis (H4o), which states, "there is no statistically significant relationship between capital structure, financial sustainability, and outreach of MFIs from the view point of managers and operation staff surveyed in northern Ghana" in favor of the alternative hypothesis 
(H4a), which stated that there is a statistically significant relationship between capital structure, financial sustainability, and outreach of MFIs from the view point of managers and operation staff in northern Ghana.

\section{Discussion of the Results}

The outcome of the study was consistent in many respects to similar empirical studies reviewed in the literature. The findings also contradicted recent empirical studies as discussed in the literature of MFIs sustainability and outreach.

\subsection{Relationship between Capital Structure and Financial Sustainability of MFIs in Northern Ghana}

The study found a positive statistically significant relationship between capital structure and financial sustainability from the point of view of managers and operation staff of MFIs surveyed in northern Ghana. This implies that if MFIs properly set out their capital structure well such as having clear equity owners and the leadership of the firm can effectively manage financial constraints issues this will result in improved financial sustainability, which in turn will be reflected in the MFIs ability to pay its debt obligation. This will then allow the MFIs to continue to operate without really depending on donor funds.

These findings are consistent with recent empirical studies such as Bogan (2012) who found that the size of an MFI's assets and an MFI's capital structure were associated with sustainability and outreach. This meant that an MFI's access to capital would increase loanable funds, which will enhance sustainability and increase outreach to the productive poor.

Additionally, Bogan (2012) further found causal evidence to support the assertion that the use of grants or donor support drives down operational self-sufficiency of MFIs. Similarly, Mohammed (2011) also found a positive relationship between financing strategies and financial sustainability of SACCOs in Uganda. Kar (2012) and Bogan (2012) uncovered a positive effect of leverage and financial sustainability of MFIs. Nyamsogoro (2010) who found that capital structure affected sustainability of rural MFIs in Tanzania further supports the findings. Kiphoech and Muturi (2014) found that capital adequacy had greater influence on MFIs sustainability in Kenya.

On the contrary, Nurmakhanova, Kretchmar, and Fedhila (2015) found that there was a negative relationship between leverage and financial sustainability of MFIs. The findings of this study also contradict that of Sekabira (2013) who found that capital structure components such as grants and debts were negatively correlated to operational and financial sustainability in Uganda and does recommend that MFIs must reduce dependence on debts and grants to rather more dependence on share capital for long-term financial sustainability. Kinde (2012) found that capital structure had rather insignificant impact on financial sustainability among Ethiopian MFIs.

\subsection{Relationship between Capital Structure and Outreach of MFIs in Northern Ghana}

The study found that there was no statistically significant relationship between capital structure and the level of outreach of an MFI's operation from the point of view of managers and operation staff in northern Ghana as statistically correlations were insignificant at $95 \%$ confidence level. This implies that the composition of MFIs capital structure did not influence the level of outreach in the views of the respondents of MFIs surveyed in northern Ghana. In other words, regardless of how well an MFI composed its capital structure in northern Ghana, this has not improved the ability of the MFI to reach out to the poorest clients in the view of respondents.

The findings contradict that of Mohammed (2011) who found that there was a positive statistically significant relationship between financing strategies and outreach of SACCOs in Uganda. Another study that contradicts the finding is Ahmed (2009) who asserted in his research paper in Bangladesh that the financial needs of the productive poor is best served by encouraging a broad range of institutions to providing efficient and responding to lending, savings and other financial services to poor people, and that this can only be done by financially sustainable MFIs.

\subsection{Relationship between Financial Sustainability and Outreach of MFIs in Northern Ghana}

The outcome of the study found that there is no statistically significant relationship between financial sustainability and outreach levels in the views of the respondents of MFIs surveyed in northern Ghana. This means that MFIs may be able to cover the loan write-offs, have their retained earning's rising every year but at a marginal rate as well as reducing default rates also marginally which leaves no room for the MFIs to increase the level of outreach both with respect to depth and breadth. This also implies that if MFIs has a wider capital base and always maintained higher working capital, possibly they would be able to provide funds to the productive poor on a sustained basis but the result suggests that the current assets are almost the same as current liabilities or marginally higher than the current liabilities; thus, MFIs are not able to increase the level of outreach. As such, MFIs may just meet their cost of operations and remain in business but has no impacts on the level of outreach.

The findings of this study are supported by Kipesha and Zhang (2013) who found that using the welfare approach the presence of negative tradeoffs between profitability and outreach to the productive poor and failed to show any presence of tradeoffs between financial sustainability and outreach measures. Zerai and Rani (2012) found in their study that outreach and sustainability were supplementing each other and this was because the study 
failed to establish a tradeoff between outreach and financial sustainability.

On the contrary, Kipesha and Zhang (2013) under the profit incentive approach uncovered that outreach to the productive poor had a positive relationship with both sustainability and outreach measures. As a result, the authors concluded that there was a possibility of a tradeoff between outreach to the productive poor with profitability measures as opposed to the outreach with financial sustainability. A further contradiction to the findings of this study is by Mohammed (2011) who found in his study that there was a positive relationship between financial sustainability and outreach of SACCOs in Uganda.

This relationship means that to the extent that MFIs are in position to cover the loan write-offs, having their retained earnings rising every year coupled with the ability to reduce default rate, this will in turn increase the level of outreach in terms of breadth and depth. Quayes (2012) found that there was a positive complementary relationship between financial sustainability and the depth of outreach thereby further contradicting the outcome of this study. Anim (2010) on the performance of MFIs and outreach in Ghana found that there exist tradeoffs between financial sustainability and reaching the productive poor.

\section{Conclusions and Practical Recommendation}

The study concludes that there is positive statistically significant relationship between capital structure and financial sustainability from the point of view of managers and operation staff of MFIs surveyed in northern Ghana. However, the study failed to find any statistically significant relationship between capital structure and outreach in the view of respondents of MFIs surveyed in northern Ghana. Similarly, the study failed to find any statistically significant relationship between financial sustainability and outreach from the view point of managers and operation staff of MFIs surveyed in northern Ghana. Consequently, the study found a positive statistically significant relationship between capital structure, financial sustainability and outreach from the point of view of managers and operation staff of MFIs surveyed in northern Ghana.

Based on the findings of the study the following policy recommendations are made:

\subsection{Merger of MFIs}

The outcome of the study indicates that by December, 2018, most MFIs may not be able to meet the capital adequacy requirements imposed by the Bank of Ghana, though majority of the MFIs are positive that they will meet these requirements by December 2018. The researchers therefore recommend that MFIs can merge their operations to become bigger and be better positioned in order to mobilize deposits and savings from their clients. This proposed merger will also reduce the proliferations of MFIs in Ghana and provide opportunity for efficiency and effectiveness in delivering services and products to the productive poor at a reduced cost, which will enhance sustainability and improve the level of outreach in northern Ghana. At the moment, there are too many MFIs in Ghana most of whom are inefficient and ineffective in their operations posing a threat to their sustainability and outreach. For example, the website of the Bank of Ghana (2016) currently has over 500 MFIs in Ghana compared with only 30 universal licensed banks.

\subsection{Enforcement of Deposit Insurance Scheme}

In September 2016, a new law on MFIs has been passed by Parliament of the Republic of Ghana, which requires that all deposits and savings of clients of MFIs must be insured so that unsuspecting clients does not lose their investments with MFIs. This law is very important and as a result, the researchers are recommending that the provisions of this law must be enforced strictly to ensure that MFIs do not violate it since doing so will jeopardize the investments of clients.

\subsection{Improvement of Supervision and Monitoring}

The researchers recommend that the level of supervision and monitoring of MFIs activities should be improved and rigorous to prevent MFIs exploiting and misusing depositors' funds. In recent times, Ghana has witnessed the operations of questionable MFIs who run away with customers' deposits as discussed in the literature of this study. Effective monitoring and supervision will prevent these operators in the microfinance industry, protect, and safeguard the investments of clients to MFIs. However, there is no need for structural changes; existing structures just need additional resources, training, and direction.

\subsection{Increased Support to MFIs from Government}

The government of Ghana needs to support the operations of MFIs to be successful by offering technical advice, training and reward successful MFIs to provide motivation for others. This is because the operations of these MFIs create jobs, provides tax revenue for national development and above all contribute significantly in the reduction of poverty. 


\section{Recommendations for Further Research}

The researchers call for further research work to be conducted on an assessment of the factors influencing the sustainability and outreach of MFIs in the remaining parts of Ghana, which will assist in policy direction by the industry regulators. This call by the researchers is necessary because the findings of this study covered only five out of the sixteen administrative regions in Ghana.

\section{References}

Adhikary, S. and Papachristou, G. (2014). Is there a trade-off between financial performance and outreach in South Asian microfinance institutions? The Journal of Development Areas, 48(4), 381-402.

Ahmed, S. (2009). Microfinance institutions in Bangladesh: Achievements and challenges, Journal of Managerial Finance 35(12), 999-1010.

Annim, S. K. (2012). Targeting the poor versus financial sustainability and external funding: Evidence of microfinance institutions in Ghana. Journal of Developmental Entrepreneurship, 17(3), 1-20.

Annim, S. K. (2010). Microfinance paradigm: Institutional performance and outreach. PhD thesis, University of Manchester, UK.

Aveh, F. K. (2011). An evaluation of the performance of MFIs in Ghana. DBA thesis, Bradford University, UK.

Ayayi, A. and Sene, M. (2010). What drives microfinance institution's financial sustainability, The Journal of Developing Areas, 44(1), pp: 303-324.

Bogan, V. (2009). Capital structure and sustainability: An empirical study of microfinance institutions, Cornell University, 454 Warren Hall, Ithaca, NY 14853.

Bogan, V., Johnson, W., and Mhlanga N. (2007). Does capital structure affect the financial sustainability of microfinance institutions? Cornell University, 454 Warren Hall, Ithaca, NY 14853.

Bogan, V. (2011). Financial inclusion, innovation, and investments: Biotechnology and capital markets working for the Poor. Singapore World Scientific, 36-52.

Bogan, V. (2012). Capital structure and sustainability: An empirical study of microfinance institutions. The review of economics and statistics, 94(4), 1045-1058.

Cull, R., Demirguc-Kunt, A., and Morduch, J. (2011). Does microfinance regulation curtail profitability and outreach? World Development, 39(5), 949-965.

Davutoglu, A. (2013). Two different poverty reduction approaches: Neoliberal market based microfinance verses social rights defender basic income. International Journal of Social Inquiry, 6(1), 39-47.

Demirguc-Kunt, A., and Klapper L. (2012). Measuring financial inclusion: The global findex database. The World Bank Development Research Group, Policy Research Working Paper 6025.

Helms, B. (2006). Access for all: Building inclusive financial systems. International Bank for Reconstruction and Development, Washington, DC.

Hermes, N. and Lensink, R. (2011). Microfinance: Its impact, outreach and sustainability. World Development, $39,875-881$.

Hermes, N., Lensik, R., and Meestres, A. (2011). Outreach and efficiency of microfinance institutions, World Development, 39(6), pp. 938-948.

Hudon, M. (2010). Management of microfinance institutions: Do subsidies matter? Journal of International Development, 22, 890-895.

Kai, H. (2009). Competition and wide outreach of microfinance institutions, Economics Bulletin, 29(4), pp: 26282639.

Kar, A. K. (2012). Does capital and financing structure have any relevance to the performance of microfinance institutions? International Review of Applied Economics, 26(3), 329-348.

Kar, A. K. (2011). Microfinance institutions: A cross-country empirical investigation of outreach and sustainability. Journal of Small Business and Entrepreneurship, 24(3), 427-446.

Kar, A. K. (2013). Mission drift in microfinance: Are the concerns really worrying? Recent cross-country results. International Review of Applied Economics, 27(1), 44-60.

Kindie, B.A. (2012). Financial sustainability of microfinance institutions in Ethiopia, European Journal of Business and Management, 4(15) pp: 1-11.

Kipesha, E.F., and Zhang, X. (2013). Sustainability, profitability and outreach tradeoffs: Evidences from microfinance institutions in East Africa, European Journal of Business and Management, 5(8), pp: 136-148.

Kimando, L. N., Kihoro, J. M., \& Njogu, G. W. (2012). Factors influencing the sustainability of microfinance institutions in Murang's Municipality. International Journal of Business and Commerce, 1(10), 21-45.

Kipkoech, J. B., and Muturu, W. (2014). Determinants of financial performance of microfinance institutions in Kenya: A case of institutions in Nakuru town. International Journal of Accounting and Financial Management, 4(6), pp. 1-16.

Leikem, K. (2012). Microfinance: A tool for poverty reduction? Honors program at the University of Rhode Island. Senior Honors Project. Available at: http://digitalcommons.uri.edu/srhonorsprog/300 
Mersland, R, and Strom, R. (2009). Performance and governance in microfinance institutions, Journal of Banking and Finance, 33, 662-669.of Investment. The American Economic Review, 48 (3), 261-297.

Mohammed, S. (2011). Financing strategies, financial sustainability and outreach of SACCOs in Uganda. Master thesis, Makerere University, Uganda.

Morduch, J. (2000). The microfinance schism. World Development, 28(4), 617-629.

Ngo, T. V., Mullineux, A. W., and Ly, A. H. (2014). The impact of scale of operation on financial performance in microfinance. Eurasian Economic Review, 4(2), 177-198.

Nurmakhanova, M., Kretzschmar, G., and Fedhila, A. (2015). Trade -off between financial sustainability and outreach of microfinance institutions. Eurasia Business and Economics Society, 5, 231-250.

Nyamsogoro, G. D. (2010). Financial sustainability of rural microfinance institutions in Tanzania, PhD thesis, University of Greenwich, Australia.

Omondi, B. E. (2014). The relationship between funding structure and financial performance of microfinance institutions in Kenya. MBA thesis, University of Nairobi, Kenya.

Pati, A. P. (2012). Regulation versus outreach and sustainability: A study of the performance of microfinance institutions in India. The IUP Journal of Bank Management, XI(4), 41-56.

Pati, A. P. (2015). Are regulatory microfinance institutions of India better off than non- regulatory ones? A comparison of performance and sustainability. Sage publications. Available at: http://par.sagepub.com

Quayes, S. (2012). Depth of outreach and financial sustainability of microfinance institutions, Applied Economics, 44(26), pp: 3421-3433. DOI: 10.1080/00036846.2011.577016

Ranjani, K. S. (2012). Regulating microfinance institutions in India: A conceptual framework. Synergy, X(1), 5162.

Sekabira, H. (2013). Capital structure and its role on performance of microfinance institutions: The Ugandan case, Sustainable Agriculture Research, 2(3), pp: 86-100.

Zerai, B. and Rani, L. (2012). Is there a tradeoff between outreach and sustainability of micro finance institutions? Evidence from Indian microfinance institutions, European Journal of Business and Management, 4(2), pp: 90-98. 